\title{
Peningkatan Hasil Belajar PKn Melalui Pendekatan Problem Solving pada Siswa Kelas V SD Inpres Andi Tonro Kota Makassar
}

\author{
Andi Baso ${ }^{1)}$ \& Nasrun Hasan ${ }^{21}$ \\ Pendidikan Pancasila dan Kewarganegaraan FKIP Universitas Muhammadiyah Makassar ${ }^{1)}$ \\ Pendidikan Pancasila dan Kewarganegaraan FKIP Universitas Muhammadiyah Makassar 2) \\ andibaso@unismuh.ac.id ${ }^{1)}$ \& nasrunhasan@unismuh.ac.id ${ }^{21}$
}

\begin{abstract}
The main problem of this study is the low learning outcomes of students, so the purpose of this study is to improve the learning outcomes of Civics through problem solving approaches in grade $\mathrm{V}$ students Inpres Andi Tonro Makassar. Research This research belongs to classroom action research. The subjects of this study were all students of grade V SD Inpres Andi Tonro Kota Makassar which amounted to 41 students consisting of 26 Men and 15 Women. The results showed the use of problem solving application can improve the learning outcomes of Civics in grade V SD Inpres Andi Tonro Makassar. It can also be seen from the average value in cycle I that is 70.37 and is in the medium category and increased in cycle II to 81.34 and is in the high category.

Keywords: Learning outcomes, problem solving, students.
\end{abstract}

\begin{abstract}
Abstrak. Masalah utama penelitaian ini adalah rendahnya hasil belajar siswa, sehingga tujuan penelitian ini adalah untuk meningkatkan hasil belajar PKn melalui pendekatan problem solving pada siswa kelas V SD Inpres Andi Tonro Makassar. Penelitian Penelitian ini tergolong penelitian tindakan berbasis kelas (classroom Action research). Subyek penelitian ini adalah seluruh murid kelas V SD Inpres Andi Tonro Kota Makassar yang berjumlah 41 murid terdiri dari 26 Laki-laki dan 15 Perempuan. Hasil penelitian menunjukkan penggunaan penerapan problem solving dapat meningkatkan hasil belajar PKn pada murid kelas V SD Inpres Andi Tonro Kota Makassar. Hal ini juga dapat dilihat dari nilai rata-rata pada siklus I yaitu 70.37 dan berada pada kategori sedang dan meningkat pada siklus II menjadi 81.34 dan berada pada kategori tinggi.
\end{abstract}

Kata kunci: Hasil belajar, problem solving, siswa. 


\section{PENDAHULUAN}

Dinamika dunia pendidikan nasional menjadi sorotan publik, khususnya bagi kalangan akademisi, pengamat, pemerintah bahkan masyarakat umum. Berbagai realita dalam dunia pendidikan mampu membawa perhatian stakeholder pendidikan untuk bersama secara kolektif memperbaiki kualitas pendidikan nasional. Beberapa komponen vital yang memang tak habisnya menjadi diskursus seperti, kontroversi penyelenggaraan Ujian Nasional (UN), upaya peningkatan kualitas guru (dengan berbagai macam instrumen kebijakan pemerintah), pengembangan model pembelajaran, media pembelajaran, peningkatan mutu infrastruktur pendidikan (sarana dan prasarana), akses informasi pendidikan yang mesti diperluas sampai ke pelosok daerah sampai kepada distribusi akses pendidikan yang bermuara pada pemerataan pendidikan di seluruh pelosok nusantara. Semua komponen utama tersebut selalu bersamaan pemenuhannya agar kualitas dan pemerataan pendidikan nasional semakin meningkat baik. Sebab pendidikan merupakan instrumen sosiokultural untuk membangun tatanan sosial masyarakat yang beradab dan berkemajuan, di tengah kompetisi dunia global.

Sebagaimana dijelaskan secara eksplisit dalam UU Sisdiknas, bahwa tujuan pendidikan nasional adalah mengembangkan kemampuan dan membentuk watak serta peradaban bangsa yang bermartabat dalam rangka mencerdaskan kehidupan bangsa, bertujuan untuk berkembangnya potensi murid didik, agar menjadi manusia yang beriman dan bertakwa kepada Tuhan YME, berakhlak mulia, sehat, berilmu, cakap, mandiri dan menjadi warga negara yang demokratis dan bertanggung jawab (UU No. 20/2003:35 tentang Sisdiknas). Entitas pendidikan nasional sebagai suatu komponen vital memang tak bisa dibiarkan begitu saja bahkan tanpa perencanaan secara matang dan komprehensif. Berbagai regulasi dibuat oleh pemerintah untuk mencapai tujuan-tujuan filofofis dan bersifat transedental. Diperlukan perencanaan yang matang pada beberapa fase penting yaitu dalam perencanaan, pelaksanaan, penilaian dan evaluasi.
Semua tahapan wajib tersebut mesti dipenuhi oleh motor utama dalam entitas pendidikan yang bernama guru. Guru sebagai pendidik profesional memiliki tugas utama yang harus dijalankannya dalam rangka mencapai tujuan pendidikan nasional tadi. Seorang guru memiliki tugas utama yaitu mendidik, mengajar, membimbing, mengarahkan, melatih, menilai dan mengevaluasi peserta didik (PP No. 74/2008:109 tentang Guru). Sangat jelas jika profesi guru bukanlah profesi tanpa makna, namun sarat akan nilai-nilai unggul (ultimate value), nilai profetis sampai kepada etis-filosifis. Mesti dipahami bahwa guru menjadi titik episentrum bagi tercapainya tujuan pendidikan nasional.

Kurikulum Tingkat Satuan Pendidikan (KTSP) menghendaki agar guru dapat merancang dan menerapkan model pembelajaran yang memungkinkan murid merasa senang dan tidak bosan terhadap materi yang diajarkan sehingga hasil belajarnya dapat meningkat. Namun, harapan tersebut belum sesuai dengan kenyataan yang ditemuai di lapangan. Masih banyak guru yang kurang memperhatikan kesesuaian antara model pembelajaran dengan materi yang diajarkan, akibatnya hasil belajar murid rendah. Keadaan ini tidak bisa dibiarkan karena akan berpengaruh dengan hasil belajar murid. Oleh karena itu, pembelajaran tersebut perlu diperbaiki agar tujuan KTSP dapat tercapai.

Pendidikan dasar bertujuan memberi bekal kemampuan dasar kepada murid untuk mengembangkan kehidupannya sebagai pribadi anggota masyarakat, warga negara dan anggota umat manusia serta mempersiapkan murid untuk mengikuti pendidikan menengah. Pendidikan dasar yang diselenggarkan di Sekolah Dasar (SD) bertujuan memberi bekal kemampuan dasar BacaTulis pengetahuan dan keterampilan dasar yang bermanfaat bagi murid sesuai tingkat perkembangannya serta mempersiapkan mereka untuk mengikuti pendidikan selanjutnya.

Komponen-komponen pendidikan dasar merupakan satu kesatuan yang turut mententukan 
keberhasilan Pendidikan Sekolah Dasar (SD), salah satu komponen yang dimaksud adalah bidang pengajaran diantaranya PKN. Guru dan murid merupakan komponen utama dalam proses pembelajaran. Guru diharapkan dapat membimbing murid sedemikian rupa, sehingga mereka dapat mengembangkan pengetahuannya sesuai dengan struktur pengetahuan bidang studi yang dipelajari, disamping harus memahami sepenuhnya materi yang diajarkan, guru juga dituntut untuk mengetahui secara tepat dimana tingkat pengetahuan murid pada awal atau sebelum mengikuti pelajaran tertentu.

Mata Pelajaran PKn merupakan salah satu instrumen fundamental dalam bingkai pendidikan nasional sebagai media bagi pembentukan karakter bangsa (nation and character building) di tengah heterogenitas atau pluralisme yang menjadi karakteristik utama bangsa Indonesia. Bangsa Indonesia memiliki ragam perbedaan dan menjadi kekayaan manusia Indonesia. Perbedaan suku, budaya, adat-istiadat, agama, ras, gender, strata sosial dan golongan/aliansi politik sangat jelas melekat dalam diri masyarakat Indonesia. Pluralitas menjadi sebuah realita dan mesti diterima sebagai kekayaan nasional bangsa Indonesia. Di tengah banyak perbedaan tersebut, sebagai suatu kesatuan nasional bangsa Indonesia harus hidup dan bergaul agar integritas nasional tetap terjaga. Implikasi logisnya adalah perlu membangun sikap inklusif, pluralis, toleran dan saling berdampingan dengan cinta dan perdamaian.

PKn didefinisikan sebagai suatu bidang kajian yang memusatkan telaahnya pada seluruh dimensi psikologis dan sosial budaya kewarganegaraan individu, dengan menggunakan ilmu politik, ilmu pendidikan sebagai landasan kajiannya atau penemuannya. Intinya yang diperkaya disiplin ilmu-ilmu lain yang relevan, dan mempunyai implikasi kebermanfaatan terhadap instrumentasi dan praksis pendidikan setiap warga negara dalam konteks sistem pendidikan nasional (Nadiroh, 2008:86).
"Dari uraian diatas dapat diasumsikan bahwa mata pelajaran PKn mempunyai nilai yang strategis dan penting dalam mempersiapkan sumber daya manusia yang unggul, handal, dan bermoral semenjak dini, maka seharusnya pembelajaran di sekolah-sekolah merupakan suatu kegiatan yang disenangi, menantang dan bermakna bagi peserta didik dan tidak menjadikan pembelajaran PKn adalah pembelajaran yang membosankan.

Berdasarkan hal-hal di atas nampak bahwa pada satu sisi betapa pentingnya peranan pendidikan PKn dalam mengembangkan pengetahuan, nilai, sikap, agar murid menjadi warga masyarakat, bangsa, dan Negara indonesia yang baik, namun di pihak lain masih banyak masalah-masalah tersebut diperlukan penelitian berkaitan dengan pembelajaran PKn".

Berdasarkan pra penelitian yang dilakukan penulis saat melakukan observasi dan di SD Inpres Andi Tonro Kota Makassar diperoleh hasil bahwa dalam pembelajaran PKn nilai hasil belajar menunjukkan bahwa rata-rata hasil ujian sekolah untuk mata pelajaran PKn mendapatkan nilai ratarata 65 sementara standar ketuntasan minimal atau kriteria ketuntasan minimal untuk mata pelajaran PKN yaitu 70. Hal tersebut merupakan sebuah permasalahan yang harus dicari jawabannya.

Rendahnya hasil pembelajaran PKn di SD Inpres Andi Tonro Kota Makassar disebabkan oleh banyak faktor diantaranya: (1) Guru dalam mengimplementasikan pelajaran PKn saat ini masih bersifat konvensional. (2) guru mengarahkan bahan/materi PKn hanya berupa informasi yang tidak mengembangkan berpikir nilai. (3) Guru hanya membentuk budaya menghafal dan bukan berpikir kritis. Sementara dari segi murid terlihat bahwa selama proses pembelajaran PKn, murid hanya pasif didalam pembelajaran. Disisi lain juga ada kecenderungan bahwa aktivitas murid dalam pembelajaran PKn masih rendah.

Mengacu pada temuan permasalahan di kelas maka peneliti bersama guru dan kepala sekolah berkolaborasi untuk mengidentifikasi penyebab permasalahannya. Didalam kolaborasi tersebut peneliti mengungkapkan hasil temuannya di kelas. Kemudian kepala sekolah memberikan 
kesempatan kepada guru untuk menanggapi temuan peneliti tersebut. Setelah diidentifikasi bahwa perlu adanya inovasi pembelajaran yang mampu mengatasi masalah tersebut agar dapat meningkatkan pemahaman murid. Salah satu faktor keberhasilan dalam proses pembelajaran adalah pendekatan mengajar, saat ini masih banyak guru yang menganut paradigma lama yaitu guru masih menganggap dalam proses pembelajaran hanya ada transfer pengetahuan dari guru kepada murid.Sudah seharusnya kegiatan belajar mengajar juga lebih mempertimbangkan murid. Alur proses belajar tidak harus berasal dari guru menuju murid, murid bisa juga saling mengajar dengan sesama murid lainnya. Alternatif pemecahan masalah adalah dengan menerapkan pendekatan Problem Solving, Pendekatan pembelajaran ini mempermudah murid dalam memahami materi yang diajarkan. Guru selama ini berasumsi bahwa dengan memberikan bahan berupa informasi, murid telah memahami materi yang diberikan guru. Guru hanya membentuk budaya menghafal dan bukan berpikir kritis karena guru menganggap bahwa dengan menghafal saja murid sudah mampu memahami dan bisa menjawab soal dengan baik. Sedangkan dari murid hanya pasif didalam kelas karena guru tidak sepenuhnya melibatkan murid secara aktif dalam mengkonstruksi pemikiran sendiri.

Berdasarkan penyebab permasalahan diatas maka peneliti, guru dan kepala sekolah menyimpulkan bahwa yang menjadi penyebab permasalahan adalah Strategi pembelajaran yang digunakan oleh guru. Oleh karena itu peneliti, guru dan kepala sekolah mengadakan pertemuan kembali untuk merefleksi dan berusaha mencari Strategi pembelajaran yang tepat untuk diterapkan pada pembelajaran PKn. Dan setelah didiskusikan bersama tercapailah sebuah kesepakatan bahwa dari selain banyak Strategi atau pendekatan yang terungkap dalam diskusi maka startegi yang dianggap cocok untuk diterapakan dalam pembelajaaran adalah pendekatan problem solving.

\section{METODE PENELITIAN}

Penelitian Penelitian ini tergolong penelitian tindakan berbasis kelas (classroom Action research). Subyek penelitian ini adalah seluruh murid kelas V SD Inpres Andi Tonro Kota Makassar yang berjumlah 41 murid terdiri dari 26 Laki-laki dan 15 Perempuan. Penerapan pendekatan pembelajaran ini dilakukan sebanyak dua siklus di mana kesulitan/kelemahan yang ditemukan pada pembelajaran pertama didiskusikan dengan pembimbing dan diupayakan perbaikan paa siklus pembelajaran selanjutnya. Adpun prosedur penelitian tindakan ini apat dijabarkan sebagai berikut. Teknik pengumpulan data yang dilakukan dalam penelitian ini adalah sebagai berikut untuk data mengenai keaktifan dan kesungguhan murid dalam mengikuti proses belajar akan diambil pada saat proses pembelajaran berlangsung dengan menggunakan pedoman observasi dan data tentang hasil belajar PKn yang diperoleh dengan menggunakan tes hasil belajar pada setiap akhir tahap. Data yang diperoleh dari pelaksanaan observasi dianalisa secara kualitatif sedangkan data hasil belajar PKn murid kelas $\mathrm{V}$ dianalisa secara kuantitatif dengan menggunakan statistik deskriptif yaitu skor rata-rata, SD Negeri Inpres Andi Tonro Kota Makassar persentase, standar deviasi, nilai minimun dan nilai maksimun yang dicapai murid setiap siklus. Untuk mengetahui skor hasil belajar murid maka digunakan rumus sebagai berikut :

$$
\mathrm{N} . \mathrm{A}=\frac{\text { skor perolehan }}{\text { skor maksimal }} \times 100
$$

Skor akhir dari hasil belajar murid dimasukkan ke dalam tabel distribusi frekuensi skor untuk menegetahui tingkat penguasaan anak yaitu sangat rendah, rendah, sedang, tinggi, dan sangat tinggi. Dengan menggunakan rumus tabel distribusi frekuensi sebagai berikut :

$$
\mathrm{R}=\text { skor Tertinggi }- \text { skor terendah }
$$

$$
\mathrm{Ki}=\frac{R}{i}+1
$$


Tabel 3.1 : Distribusi Frekuensi Skor

\begin{tabular}{lcc}
\hline No & Kemampuan & Tingkat penugasan \\
\hline 1 & $88-100$ & Sangat tinggi Tingg \\
2 & $75-87$ & Sedang \\
3 & $62-74$ & Rendah \\
4 & $49-61$ & Sangat rendah \\
5 & $0-48$ & \\
\hline
\end{tabular}

Indikator dari penilaian ini adalah apabila terjadi peningkatan skor rata-rata hasil belajar PKn dari tahap pertama ke tahap kedua. Perlakuan dianggap berhasil apabila mencapai Kriteria Ketuntasan Minimal (KKM) mencapai 70 dan ketuntasan secara klasikal harus mengcapai $85 \%$ dari 41 murid.

\section{PEMBAHASAN}

\section{Aktivitas Belajar Murid Siklus I}

Hasil belajar murid pada siklus I setelah dilaksanakan observasi terhadap murid pada proses belajar mengajar, maka diperoleh hasilnya sebagai berikut :

Tabel 1 Aktivitas Belajar Murid pada Siklus I

\begin{tabular}{|c|c|c|c|c|c|c|}
\hline \multirow[b]{2}{*}{ No } & \multirow[b]{2}{*}{ Aktivitas } & \multicolumn{3}{|c|}{ Frekuensi } & \multirow{2}{*}{$\begin{array}{l}\text { Rata } \\
\text { rata }\end{array}$} & \multirow[b]{2}{*}{$\%$} \\
\hline & & I & II & III & & \\
\hline 1 & $\begin{array}{l}\text { Mengidentifikasi } \\
\text { keadaan siswa } \\
\text { berupa kehadiran, } \\
\text { minat dan kesiapan } \\
\text { belajar. }\end{array}$ & 18 & 19 & 21 & 19,34 & 47,17 \\
\hline 2 & $\begin{array}{l}\text { murid } \\
\text { mendefinisikan } \\
\text { masalah dari } \\
\text { berbagai peristiwa }\end{array}$ & 19 & 20 & 22 & 20.34 & 49.61 \\
\hline 3 & $\begin{array}{l}\text { Murid } \\
\text { mendiagnosis } \\
\text { berbagai } \\
\text { peneyebab } \\
\text { terjadinya masalah }\end{array}$ & 14 & 16 & 21 & 17.00 & 41.46 \\
\hline 4 & $\begin{array}{l}\text { Murid mampu } \\
\text { memecahkan } \\
\text { masalah yang telah } \\
\text { diberikan oleh } \\
\text { guru dalam diskusi } \\
\text { kelompok }\end{array}$ & 12 & 14 & 18 & 14.67 & 35.78 \\
\hline 5 & $\begin{array}{l}\text { Murid mampu } \\
\text { yang mampu } \\
\text { mengemukakan } \\
\text { pendapatnya }\end{array}$ & 10 & 14 & 18 & 14.00 & 34.15 \\
\hline 6 & $\begin{array}{l}\text { Murid aktif dalam } \\
\text { diskusi }\end{array}$ & 10 & 18 & 22 & 16.67 & 40.66 \\
\hline \multicolumn{5}{|c|}{ Jumlah rata-rata } & 17.00 & 41.47 \\
\hline
\end{tabular}

Sumber: Hasil Observasi Belajar Murid Siklus I
Berdasarkan tabel 1 menunjukkan bahwa distribusi dan presentase aktivitas murid pada siklus I penerapan pendekatan Problem Solving yang diperoleh melalui lembar observasi diperoleh presentase adanya peningkatan dengan penjelasan sebagai berikut :

a. Jumlah murid yang hadir, minat dan siap dalam belajar pada pertemuan I, II, dan III terjadi peningkatan dari 18, 19 menjadi 21.

b. Jumlah Murid yang mampu mendefinisikan masalah dari berbagai peristiwa selama proses pembelajaran berlangsung pada pertemuan I, II dan III terjadi peningkatan dari 19, 20 dan 22.

c. Jumlah murid yang mampu mendiagnosis berbagai penyebab terjadinya masalah pada proses pembelajaran pada pertemuan I, II dan ke III terjadi peningkatan dari 14, 16 dan 21.

d. Murid yang mampu memecahkan masalah yang telah diberikan oleh guru saat proses belajar mengajar berlangsung pada pertemuan I, II, dan ke III terjadi peningkatan dari 12, 14, dan 18

e. Murid yang mampu menetapkan jawaban sementara dari masalah pada pertemuan I, II dan ke III terjadi peningkatan dari 10, 18 dan 22

f. Murid yang aktif dalam diskusi pada pertemuan I, II dan ke III terjadi peningktan dari 10, 18, dan 22.

Berdasarkan hasil observasi tersebut di atas disimpulkan bahwa pada siklus pertama pertemuan ketiga sudah mengalami peningkatan dari pertemuan pertama dan pertemuan kedua. Dalam proses pembelajaran pertemuan ketiga ini peneliti memperbaiki kesalahan-kesalahan yang terjadi pada pertemuan pertama dan kedua namun masih memerlukan perbaikan lagi pada siklus II. Hal ini terlihat banyaknya murid yang tidak berkonsentrasi dan masih banyak ditemui kesulitan-kesulitan dalam proses pembelajaran berlangsung pada saat melalui motode Problem solving. Ada juga beberapa murid kadang minta isin kepada guru untuk keluar wc yang menghambat proses pembelajaran, hal ini memancing juga perhatian temannya yang lain untuk keluar masuk kelas kelas. 


\section{Hasil Tes Belajar Murid Siklus I}

Pada akhir siklus I ini, diperoleh gambaran tentang hasil belajar PKN di kelas $\mathrm{V}$ yang menjadi subjek penelitian. Tes akhir siklus ini diikuti oleh semua murid kelas V SD. Inpres Andi Tonro yang berjumlah 41 orang. Adapun data nilai hasil tes murid pada tes akhir siklus I ini dapat dilihat pada tabel 2 berikut ini:

Tabel 2 Statistik Hasil Tes Murid pada Siklus I

\begin{tabular}{cc}
\hline Statistik & Nilai Statistik \\
\hline Subjek & 41 \\
Nilai ideal & 100 \\
Nilai tertinggi & 85 \\
Nilai terendah & 40 \\
Rentang Nilai & 45 \\
Nilai rata-rata & 66.60 \\
\hline
\end{tabular}

Sumber: Analisis data hasil tes murid

Tabel 2 diperoleh informasi bahwa nilai rata-rata hasil belajar Murid V SD. Inpres Andi Tonro dalam menyelesaikan soal PKN setelah proses belajar mengajar melalui pendekatan Problem solving yang dilaksanakan pada Siklus I adalah 66.60 dengan nilai ideal yang mungkin dicapai 100. Sedangkan secara individual, nilai yang dicapai responden tersebar dari nilai terendah 40 dari nilai minimum ideal yang mungkin dicapai 0 sampai dengan nilai tertinggi 85 dari nilai ideal yang mungkin dicapai 100 dengan rentang nilai 40. Jika nilai penguasaan murid di atas dikelompokkan ke dalam lima kategori maka diperoleh distribusi frekuensi nilai seperti ditunjukkan pada Tabel 4.5 berikut ini:

Tabel 3 Distribusi Frekuensi dan Persentase Nilai Hasil Belajar Murid kelas V SD. Inpres Andi Tonro pada Siklus I

\begin{tabular}{lcccc}
\hline No & Skor & Kategori & Frekuensi & $\%$ \\
\hline 1. & $88-100$ & Sangat Tinggi & 4 & 9.76 \\
2. & $75-87$ & Tinggi & 10 & 24.40 \\
3. & $62-74$ & Sedang & 11 & 26.83 \\
4. & $49-61$ & Rendah & 11 & 26.83 \\
5. & $0-48$ & Sangat & 5 & 12.19 \\
& \multicolumn{5}{c}{ Rendah } & & \\
\hline \multicolumn{5}{c}{ Jumlah }
\end{tabular}

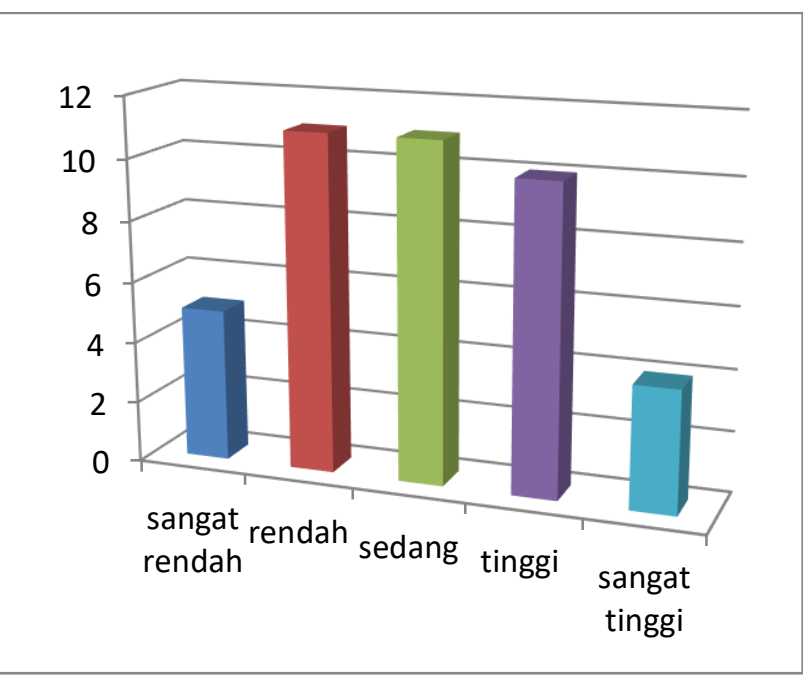

Gambar1 Diagram Batang Kategori Ketuntasan Hasil Belajar Siklus I

Berdasarkan tabel 3 di atas dapat dikemukakan bahwa dari 41 murid Kelas $V$ SD. Inpres Andi Tonro murid yang masuk dalam kategori sangat rendah $12.19 \%, 26.83 \%$ masuk dalam kategori rendah, $26.83 \%$ masuk dalam kategori sedang, $24.40 \%$ masuk dalam kategori baik dan 9.76 murid dalam kategori sangat tinggi.

Nilai rata-rata hasil belajar murid yang diperoleh setelah proses belajar mengajar selama Siklus I berlangsung yaitu sebesar 66.60. Setelah dikategorisasikan berdasarkan tabel di atas, mengetahui bahwa tingkat hasil belajar murid pada mata pelajaran PKN kelas V SD. Inpres Andi Tonro berada ada kategori sedang.

Apabila tes hasil belajar murid pada Siklus I kemudian dikategorikan dalam kriteria ketuntasan minimum yang berlaku di V SD Inpres Andi Tonro untuk mata pelajaran PKN maka diperoleh persentase ketuntasan belajar murid pada Siklus I seperti pada Tabel 4 berikut.

Tabel 4 Deskripsi Ketuntasan Belajar Murid kelas V SD. Inpres Andi Tonro pada Siklus I

\begin{tabular}{|c|c|c|c|}
\hline $\begin{array}{c}\text { kriteria } \\
\text { Ketuntasan }\end{array}$ & Kategori & Frekuensi & Persen \\
\hline $0-69$ & Tidak tuntas & 17 & 41.46 \\
\hline $70-100$ & Tuntas & 24 & 58.54 \\
\hline \multicolumn{2}{|c|}{ Jumlah } & 41 & 100 \\
\hline
\end{tabular}




\section{Iurnal Eetika Demokrasi}

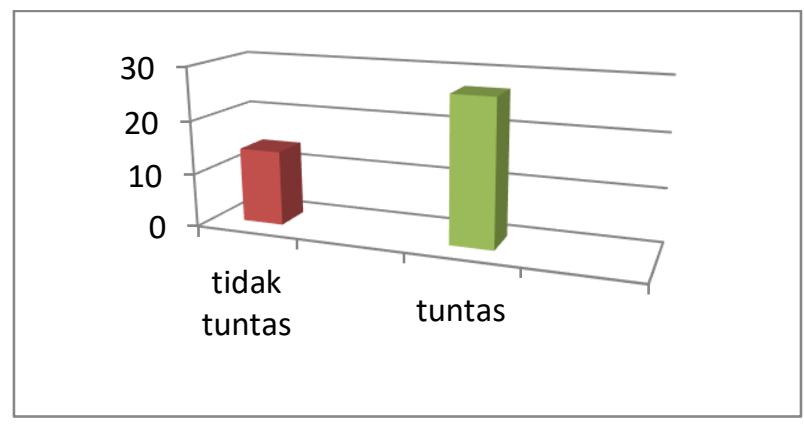

Gambar 2 Diagram Batang Ketuntasan Siklus I

Tabel 4 dapat dilihat bahwa persentase ketuntasan belajar murid setelah diajar melalui Metode Problem solving dalam mata pelajaran PKN sebesar $41.46 \%$ atau 17 orang murid dari 41 orang murid termasuk dalam kategori tidak tuntas, dan $58.54 \%$ atau 24 orang murid dari 41 orang murid termasuk dalam kategori tuntas. Hal tersebut menunjukkan bahwa masih terdapat 17 murid perlu perbaikan karena belum mencapai kriteria ketuntasan minimum yang ditetapkan yaitu 70.00.

\section{Aktivitas Belajar Murid Siklus II}

Tabel 5 Aktivitas Belajar Murid pada Siklus II

\begin{tabular}{|c|c|c|c|c|c|c|}
\hline \multirow[b]{2}{*}{$\begin{array}{l}\mathbf{N} \\
\mathbf{0}\end{array}$} & \multirow[b]{2}{*}{ Aktivitas } & \multicolumn{3}{|c|}{ Frekuensi } & \multirow{2}{*}{$\begin{array}{l}\text { Rata } \\
\text { rata }\end{array}$} & \multirow[b]{2}{*}{$\%$} \\
\hline & & 1 & II & III & & \\
\hline 1 & $\begin{array}{l}\text { Mengidentifikasi } \\
\text { keadaan siswa } \\
\text { berupa kehadiran, } \\
\text { minat dan kesiapan } \\
\text { belajar. }\end{array}$ & 30 & 35 & 39 & 34.67 & $\begin{array}{c}84.5 \\
6\end{array}$ \\
\hline 2 & $\begin{array}{l}\text { murid } \\
\text { mendefinisikan } \\
\text { masalah dari } \\
\text { berbagai peristiwa }\end{array}$ & 25 & 30 & 36 & 30.34 & $\begin{array}{c}74.0 \\
0\end{array}$ \\
\hline 3 & $\begin{array}{l}\text { Murid } \\
\text { mendiagnosis } \\
\text { berbagai } \\
\text { peneyebab } \\
\text { terjadinya masalah }\end{array}$ & 30 & 35 & 37 & 34.00 & $\begin{array}{c}82.9 \\
3\end{array}$ \\
\hline 4 & $\begin{array}{l}\text { Murid mampu } \\
\text { memecahkan } \\
\text { masalah yang telah } \\
\text { diberikan oleh } \\
\text { guru dalam diskusi } \\
\text { kelompok }\end{array}$ & 30 & 33 & 38 & 33.67 & $\begin{array}{c}82.1 \\
2\end{array}$ \\
\hline 5 & $\begin{array}{l}\text { Murid mampu } \\
\text { mengemukakan } \\
\text { pendapatnya }\end{array}$ & 35 & 38 & 40 & 37.67 & $\begin{array}{c}91.8 \\
8\end{array}$ \\
\hline 6 & $\begin{array}{l}\text { Murid aktif dalam } \\
\text { diskusi }\end{array}$ & 30 & 36 & 40 & 35.33 & $\begin{array}{c}86.1 \\
7\end{array}$ \\
\hline \multicolumn{5}{|c|}{ Jumlah rata-rata } & 34.28 & $\begin{array}{c}83.6 \\
1\end{array}$ \\
\hline
\end{tabular}

Sumber: Hasil Observasi Belajar Murid Siklus II
Dendidikan Dancasila dan Xewarganegaraan Volume III No. 1 Januari 2018 ISSN e-2615-4374 ISSN p-2540-8763

Berdasarkan hasil observasi yang dilakukan selama proses pelaksanaan tindakan pada siklus kedua pada aspek guru diperoleh data bahwa semua indikator yang yang menjadi penilaian semuanya sudah berjalan dengan baik, pada siklus kedua sudah sangat bagus. Dalam proses pembelajaran siklus kedua ini peneliti cara mengajar guru sudah sesuai dengan metode Problem solving sehingga suasana belajar menjadi aktif dengan meningkatkan interaksi antara murid dengan guru serta murid dengan murid, sehingga suasana lebih menyenangkan. Sebagian besar murid telah mampu menyelesaikan soal yang dibuat sendiri dan soal yang dibuat oleh teman yang lainnya. Untuk lebih jelasnya peningkatan aktivitas murid dalam proses pembelajaran dapat dilihat pada data berikut:

a. Jumlah murid yang hadir, minat dan siap dalam belajar pada pertemuan I, II, dan III terjadi peningkatan dari 30, 35 menjadi 39.

b. Jumlah Murid yang mampu mendefinisikan masalah dari berbagai peristiwa selama proses pembelajaran berlangsung pada pertemuan I, II dan III terjadi peningkatan dari 25, 30 dan 36.

c. Jumlah murid yang mampu mendiagnosis berbagai penyebab terjadinya masalah pada proses pembelajaran pada pertemuan I, II dan ke III terjadi peningkatan dari 30, 35 dan 37.

d. Murid yang mampu memecahkan masalah yang telah diberikan oleh guru saat proses belajar mengajar berlangsung pada pertemuan I, II, dan ke III terjadi peningkatan dari 30, 33, dan 38

e. Murid yang mampu menetapkan jawaban sementara dari masalah pada pertemuan I, II dan ke III terjadi peningkatan dari 35, 38 dan 40

f. Murid yang aktif dalam diskusi pada pertemuan I, II dan ke III terjadi peningktan dari 30,36 , dan 40.

Jadi pada umumnya, aktivitas murid dapat dikatakan mengalami peningkatan dari Siklus I dan Siklus II.

\section{Hasil Tes Belajar Murid Siklus II}

Siklus II merupakan lanjutan dari siklus I yang telah mengalami refleksi, sehingga dari hasil tes pada siklus I kita bisa melihat bagaimana perkembangan hasil belajar murid kelas II terhadap 
mata pelajaran PKN setelah tindakan kelas yaitu metode Problem solving. Tes akhir siklus II ini diikuti oleh semua murid kelas $V$ yang berjumlah 41 orang. Adapun data nilai hasil tes murid pada akhir siklus II dapat dilihat pada tabel 6 berikut ini.

Tabel 6 Statistik Hasil Tes Murid pada Siklus II

\begin{tabular}{cc}
\hline Statistik & Nilai Statistik \\
\hline Subjek & 41 \\
Nilai ideal & 100 \\
Nilai tertinggi & 95 \\
Nilai terendah & 65 \\
Rentang Nilai & 45 \\
Nilai rata-rata & 81.71 \\
\hline
\end{tabular}

Sumber: Analisis data hasil tes murid

Tabel 6 diperoleh informasi bahwa nilai ratarata hasil belajar PKN Murid kelas V SD. Inpres Andi Tonro setelah proses belajar mengajar melalui Metode Problem solving yang dilaksanakan pada Siklus II adalah 81.71 dengan nilai ideal yang mungkin dicapai 100. Sedangkan secara individual, nilai yang dicapai responden tersebar dari nilai terendah 65 dan nilai tertinggi 95 dari nilai ideal yang dicapai 100 dengan rentang nilai 45 . Jika nilai penguasaan murid di atas dikelompokkan ke dalam lima kategori maka diperoleh distribusi frekuensi nilai seperti ditunjukkan pada Tabel 4.9 berikut ini. Tabel 7 Distribusi Frekuensi dan Persentase Skor Hasil Belajar Murid kelas V SD. Inpres Andi Tonro pada Siklus II

\begin{tabular}{ccccc}
\hline No & Skor & Kategori & Frekuensi & $\%$ \\
\hline 1. & $88-100$ & Sangat Tinggi & 12 & 29.27 \\
2. & $75-87$ & Tinggi & 15 & 36.58 \\
3. & $62-74$ & Sedang & 14 & 34.15 \\
4. & $49-61$ & Rendah & 0 & 0.00 \\
5. & $0-48$ & Sangat & 0 & 0.00 \\
& & Rendah & 41 & 100.00 \\
\hline \multicolumn{5}{c}{ Jumlah }
\end{tabular}

Sumber: Analisis data hasil tes murid

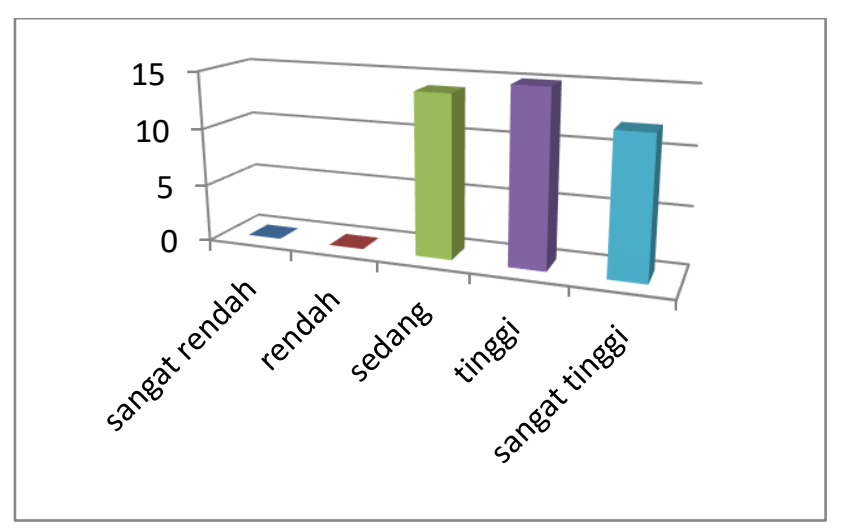

Gambar 3 Diagram Batang Kategori Ketuntasan Hasil Belajar Siklus II

Berdasarkan tabel 7 menunjukkan dari 41 murid Kelas V SD. Inpres Andi Tonro terdapat tidak ada murid masuk dalam kategori sangat rendah, dan tidak ada murid yang masuk dalam kategori rendah, 34.15\% masuk dalam kategori sedang, $36.58 \%$ masuk dalam kategori baik dan $29.27 \%$ masuk dalam kategori sangat tinggi.

Nilai rata-rata hasil belajar murid yang diperoleh setelah proses belajar mengajar selama Siklus II berlangsung yaitu sebesar 81.71 Setelah dikategorisasikan berdasarkan tabel di atas, mengetahui bahwa tingkat kemampuan Murid kelas V SD. Inpres Andi Tonro berada ada kategori Tinggi.

Apabila tes hasil belajar murid pada Siklus II kemudian dikategorikan dalam kriteria ketuntasan minimum yang berlaku di SD. Inpres Andi Tonro untuk mata pelajaran PKN maka diperoleh persentase ketuntasan belajar murid pada Siklus II seperti pada Tabel 8.

Tabel 8 Deskripsi Ketuntasan Belajar Murid kelas V SD. Inpres Andi Tonro pada Siklus II

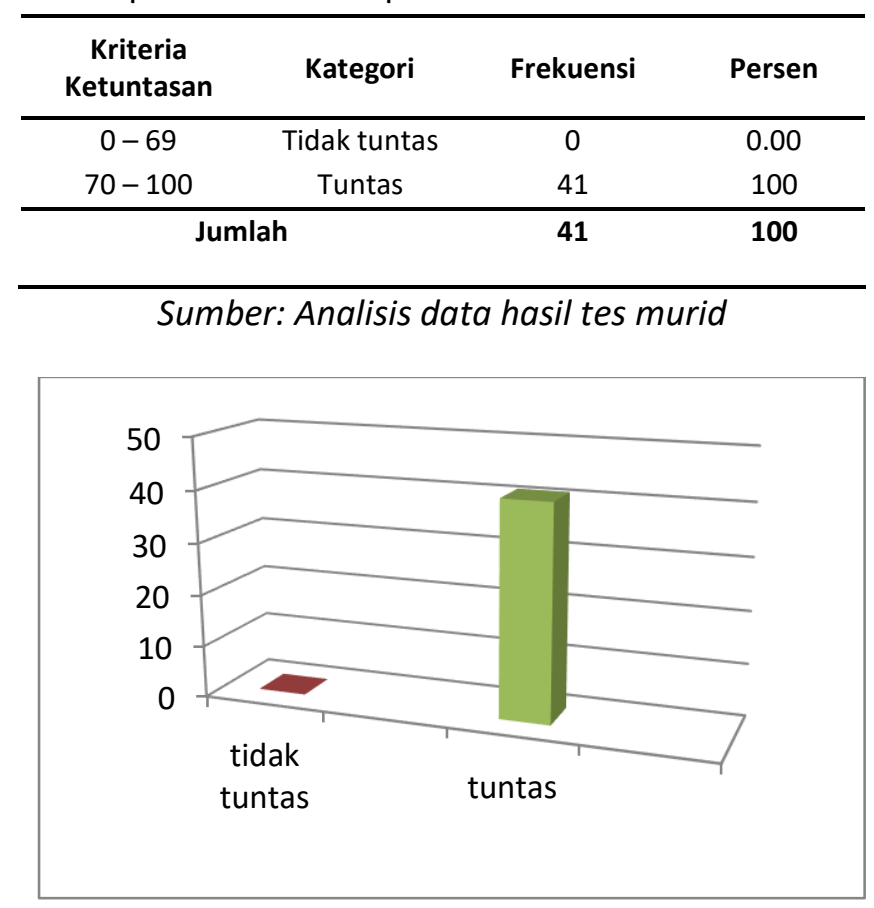

Gambar 4 Diagram Batang Ketuntasan Hasil Belajar Siklus II 
Tabel 8 dapat dilihat bahwa persentase ketuntasan belajar murid setelah diterapkan metode Problem solving pada mata pelejaran PKN sebesar 41 murid termasuk dalam kategori tuntas dan tidak ada murid masuk dalam kategori tidak tuntas. Hal tersebut menunjukkan bahwa jumlah murid yang berada dalam kategori tuntas mengalami peningkatan yakni 24 orang atau 58.54\% pada Siklus I, kemudian naik menjadi 41 orang atau $100 \%$ pada Siklus II. Hal ini juga menunjukkan bahwa ketuntasan hasil belajar murid diatas $85 \%$. Secara umum pembelajaran PKN melalui Metode Problem solving kelas V SD. Inpres Andi Tonro sudah bisa mengantar murid untuk lebih mudah memahami materi pelajaran yang diberikan yaitu NKRI.

\section{Hasil Aktivitas belajar Murid}

Tabel 9 Rata-rata aktivitas Belajar Siklus I dan II

\begin{tabular}{|c|c|c|c|c|c|}
\hline \multirow{2}{*}{ No } & \multirow{2}{*}{ Aktivitas } & \multicolumn{2}{|c|}{ Siklus I } & \multicolumn{2}{|c|}{ Siklus II } \\
\hline & & Frek & $\%$ & Frek & $\%$ \\
\hline 1 & $\begin{array}{l}\text { Mengidentifikas } \\
\text { i keadaan siswa } \\
\text { berupa } \\
\text { kehadiran, } \\
\text { minat dan } \\
\text { kesiapan } \\
\text { belajar. }\end{array}$ & 19.34 & 47.17 & 34.67 & 84.56 \\
\hline 2 & $\begin{array}{l}\text { Murid } \\
\text { mendefinisikan } \\
\text { masalah dari } \\
\text { berbagai } \\
\text { peristiwa }\end{array}$ & 20.34 & 49.61 & 30.34 & 74.00 \\
\hline 3 & $\begin{array}{l}\text { Murid } \\
\text { mendiagnosis } \\
\text { berbagai } \\
\text { peneyebab } \\
\text { terjadinya } \\
\text { masalah }\end{array}$ & 17.00 & 41.46 & 34.00 & 82.93 \\
\hline 4 & $\begin{array}{l}\text { Murid mampu } \\
\text { memecahkan } \\
\text { masalah yang } \\
\text { telah diberikan } \\
\text { oleh guru } \\
\text { dalam diskusi } \\
\text { kelompok }\end{array}$ & 14.67 & 35.78 & 33.67 & 82.12 \\
\hline 5 & $\begin{array}{l}\text { Murid mampu } \\
\text { yang mampu } \\
\text { mengemukaka } \\
\mathrm{n} \text { pendapatnya }\end{array}$ & 14.00 & 34.15 & 37.67 & 91.88 \\
\hline 6 & $\begin{array}{l}\text { Murid aktif } \\
\text { dalam diskusi }\end{array}$ & 16.67 & 40.66 & 35.33 & 86.17 \\
\hline & & & 41.47 & & 83.61 \\
\hline
\end{tabular}

Sumber: Hasil Observasi Belajar Murid Siklus I dan II
Hasil perbandingan aktivitas belajar murid pada siklus pertama dan kedua yang terdapat pada table di atas, maka hasilnya dapat digambarkan pada diagram di bawah ini :

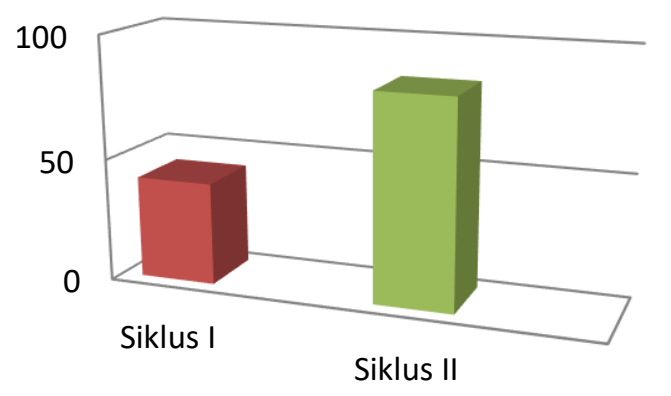

Gambar 5 Diagram Batang Tingkat Aktivitas Belajar Murid Siklus I dan Siklus II

Berdasarkan hasil observasi yang dilakukan selama proses pelaksanaan tindakan pada siklus kedua pada aspek guru diperoleh data bahwa semua indikator yang yang menjadi penilaian semuanya sudah berjalan dengan baik, pada siklus kedua sudah sangat bagus. Dalam proses pembelajaran siklus kedua ini peneliti cara mengajar guru sudah sesuai dengan metode Problem solving sehingga suasana belajar menjadi aktif dengan meningkatkan interaksi antara murid dengan guru serta murid dengan murid, sehingga suasana lebih menyenangkan. Sebagian besar murid telah mampu menyelesaikan soal yang dibuat sendiri dan soal yang dibuat oleh teman yang lainnya. Jadi pada umumnya, aktivitas murid dapat dikatakan mengalami peningkatan dari Siklus I dan Siklus II.

\section{Hasil Tes Belajar Murid}

Hasil analisis secara deskriptif kualitatif pada hasil belajar murid V SD Inpres Andi Tonro. Berdasarkan peningkatan persentase aktivitas belajar murid dalam proses pembelajaran menunjukkan peningkatan ini dibuktikan pada siklus I aktivitas murid mengikuti proses pembelajaran terlihat banyaknya murid yang tidak berkonsentrasi dan masih banyak ditemui kesulitan-kesulitan dalam proses pembelajaran berlangsung pada saat melalui motode Problem solving karena guru tidak melakukan apersepsi 
sehingga minat murid untuk belajar masih rendah, guru tidak memberikan penjelasan singkat/gambaran umum tentang materi yang akan dipelajarari sehingga sebagai konsep awal dalam melaksanakan tugas yang akan diberikan, guru tidak menyampaikan untuk menetapkan jawaban sementara dari masalah tersebut. Dugaan jawaban ini tentu saja didasarkan kepada data yang telah diperoleh, guru tidak menguji kebenaran jawaban murid dimana murid harus berusaha untuk memecahkan masalah sehingga betul-betul yakin bahwa jawaban itu cocok, dan guru tidak memberikan penghargaan kepada kelompok yang memiliki nilai tertinggi. Sedangkan pada siklus II menunjukkan bahwa respon yang baik murid sebagian besar murid telah mampu menyelesaikan soal yang dibuat sendiri dan soal yang dibuat oleh teman yang lainnya karena peran guru sudah sangat baik dalam proses pembelajaran dan mengarhkan murid untuk menetapkan jawaban sementara sampai pada menyimpulkan materi yang diberikan. Hal ini berpengaruh terhadap hasil belajar murid dari siklus I ke siklus II mengalami peningkatan.

Untuk melihat peningkatan hasil belajar PKN melalui Metode Problem solving berdasarkan hasil tes untuk setiap siklus akan disajikan secara sederhana pada tabel 10 berikut:

Tabel 10 Gambaran Peningkatan Hasil Belajar Murid kelas V SD Inpres Andi Tonro

\begin{tabular}{|c|c|c|c|c|c|c|c|}
\hline \multirow{2}{*}{$\begin{array}{l}\text { Hasil } \\
\text { Tes }\end{array}$} & \multicolumn{2}{|c|}{ Ketuntasan } & \multicolumn{4}{|c|}{ Skor } & \multirow[t]{2}{*}{$\%$} \\
\hline & $T$ & TT & I & $\mathbf{T}$ & $\mathbf{R}$ & Rata & \\
\hline $\begin{array}{l}\text { Siklus } \\
\text { I }\end{array}$ & 24 & 17 & 100 & 90 & 40 & 66.60 & $\begin{array}{c}58.5 \\
4\end{array}$ \\
\hline $\begin{array}{l}\text { Siklus } \\
\text { II }\end{array}$ & 41 & 0 & 100 & 100 & 70 & 81.71 & 100 \\
\hline
\end{tabular}

Sumber: Analisis data hasil tes murid

Tabel 10 di atas dapat dilihat bahwa nilai rata-rata hasil belajar PKN Murid kelas V SD. Inpres Andi Tonro yang dilaksanakan dalam dua siklus mengalami peningkatan pada akhir siklus I nilai rata-rata yang diperoleh murid adalah 66.60 dan berada pada kategori Sedang, sedangkan pada akhir siklus II nilai rata-rata yang diperoleh murid adalah 81.71 dan berada pada kategori yang tinggi.
Dari hasil ini menunjukkan adanya peningkatan nilai rata-rata hasil belajar PKN Murid kelas V SD. Inpres Andi Tonro melalui pendekatan Problem solving dari $58.54 \%$ menjadi $100 \%$. Besarnya persentase peningkatan hasil belajar murid berdasarkan kriteria ketuntasan belajarnya adalah $41.46 \%$. Ini berarti murid yang mengalami peningkatan hasil belajar dari Siklus I ke Siklus II adalah 24 orang murid dari 41 murid.

Hasil analisis deskriptif kuantitatif menunjukkan bahwa akhir siklus I, skor rata-rata hasil belajar murid 66.60 dari skor ideal yang mungkin dicapai adalah 100 dan berada pada kategori "sedang". Dan pada akhir siklus II, skor rata-rata hasil belajar murid mencapai 81.71 dari skor ideal yang mungkin dicapai adalah 100 dan berada pada kategori "tinggi". Dengan demikian hasil belajar PKn dilihat dari skor hasil belajar murid kelas V SD Inpres Andi Tonro mengalami peningkatan dari siklus I ke siklus II. Jadi penerapan pendekatan problem solving dalam proses pembelajaran khusunya untuk mata pelajaran PKn yaitu dapat melibatkan murid secara aktif dalam menekankan pada penemuan dan pemecahan masalah secara berkelanjutan maka mendorong murid untuk berpikir secara ilmiah, praktis, intuitif dan bekerja atas dasar inisiatif sendiri, menumbuhkan sikap objektif, jujur dan terbuka.

\section{KESIMPULAN}

Berdasarkan rumusan masalah, hasil analisis data dan pembahasan, maka hasil penelitian ini dapat disimpulkan bahwa penggunaan penerapan problem solving dapat meningkatkan hasil belajar PKn pada murid kelas V SD Inpres Andi Tonro Kota Makassar. Hal ini juga dapat dilihat dari nilai ratarata pada siklus I yaitu 70.37 dan berada pada kategori sedang dan meningkat pada siklus II menjadi 81.34 dan berada pada kategori tinggi.

\section{DAFTAR PUSTAKA}

[1] Aprilio. (2011). Langkah-Langkah Pendekatan Problem Solving. Broward kl2.fl.us/Ci/Whatsnew/strategies and such/ strategies/thinkpairshare.html (di akses pada tanggal 22 Maret 2017)

[2] Arini. (2011). Model Pembelajaran Kooperatif (Cooperatif Learning) dan Aplikasinya Sebagai 
Upaya Peningkatan Kualitas Pembelajaran. Online dari www.Depdiknas.go.id. di akses pada tanggal 22 Maret 2017)

[3] Asyirint, Gustaf. (2010). Pembelajaran Problem Solving. Online dari www. Google.com. (di akses pada tanggal 12 Oktober 2017)

[4] Damawanti. (2006). Belajar dan Pembelajaran. BT. Asdi Mahasatya, Jakarta

[5] Djamarah, Bahri dan Aswan Zain. (2002). Staretgi Belajar Mengajar. PT. Rineka Cipta: Jakarta.

[6] Haling, Abd. (2004), Belajar Pembelajaran. FIP UNM: Makassar

[7] Hamalik, O dan Wiratmojo. (2002). Media Pendidikan. PT Citra Adiya Bakti. Bandung.

[8] Hamalik, O. (2001). Proses Belajar Mengajar. Bumi Aksara: Bandung

[9] Kaelan. (2010). Pendidikan Pancasila. Yogyakarta: Paradigma

[10] Kamboja, Amir. (2011). Problem Solving Mathematics. Online dari http://www.mathgoodies.com/articles/problem_ solving.shtm.Di akses tanggal 12/10/2017)

[11] Lawson. (1991). Pembelajaran Problem Solving. Online dari http/www.Lawson.blogspot.com. (Di akses 10/08/2017)

[12] Lovitt. (1989). Pendekatan pememcahan Masalah. Online dari http/www.Lovitt.blogspot.com (Di akses 10/08/2017)

[13] Mulyasa. (2009). Penelitian Tindakan Kelas. Bandung: Pt. Remaja Rosdakarya.

[14] Nadiroh. (2008). Sistem Pendidikan Nasional. Online dari http/www.Kasim.blogspot.com (Di akses 10/08/2017)

[15] Poerwadarminta, W.JS. (1991). Kamus Bahasa Indonesia. Balai Pustaka: Jakarta.

[16] Qrustain. (201)1. Problem Solving. Onlilne. www. Google.com. (Di akses pada tanggal 22 Maret 2017)

[17] Rahadi, (2003). Faktor-faktor yang mempengaruhi hasil belajar. Online dari www.e-dukasi.com (Diakses 09/010/2017)

[18] Rakhmat, cecep. (1998). Evaluasi pengajaran. Pndidikan Guru Sekolah Dasar. Depdikbud.

[19] Sadiman, dkk. (1996). Media Pendidikan. Pustekkom dikbud dan Raja Grafindo: Jakarta.

[20] Sanjaya, Wina. (2006). Strategi Pembelajaran. Jakarta: Kencana Prenada Media Group Slameto. 1995. Belajar dan Faktor-faktor yang Mempengaruhinya. Rineka Cipta. Jakarta

[21] Slameto. (1995). Belajar dan Faktor-faktor yang Mempengaruhinya (edisi II). PT. Rineka Cipta: Jakarta

[22] Solihatin \& Raharjo. Pembelajaran Kooperatif. Jakarta: Balai Pustaka

[23] Syafri. (2009). Faktor-faktor yang mempengaruhi hasil belajar. PT. Rineka Cipta: Jakarta

[24] Suardi, S. (2018). Peningkatan Hasil Belajar Sosiologi Pokok Bahasan Interaksi Sosial Melalui
Metode Diskusi pada Siswa Kelas X MA. Muhammadiyah Panaikang Kacamatan Bissappu Kabupten Bantaeng. " JURNAL ETIKA DEMOKRASI (JED)" PRODI PPKn FKIP UNISMUH MAKASSAR, 2(1).

[25] Tiro, Arif, Muhammad. (1999). Dasar-Dasar Statistika. Makassar: Badan Penerbit Ujung Pandang.

[26] Undang-Undang Republik Indonesia No. 20 Tahun (2003) Tentang Sistem Pendidikan Nasional. CV Dewi: Jakarta

[27] Undang-Undang Republik Indonesia No. 74 Tahun (2008) Tentang Guru. Cv Dewi: Jakarata

[28] Wiriatmojo. (2005). Psikologi Belajar. Jakarta: Rineka Cipta 